\title{
Growth and Yield Response of Sweet Potato (Ipomoea batatas L. Lam) Varieties to Lowland Agro-Ecology of Raya Azebo, Ethiopia
}

\author{
Haileslassie Gebremeskel ${ }^{1}$ \\ Kedir Jaleto ${ }^{2}$ (iD \\ Wakuma Biratu ${ }^{3}$ \\ Haile Abebe ${ }^{4}$ \\ ${ }_{1,2,3,4}$ Department of Horticulture, Ethiopian Institute of Agricultural Research, Mehoni Agricultural Research \\ Center, Maichew, Ethiopia \\ Email: hailenatirosa@gmail.com Tel:+251-910145814. \\ Email: kiedireiarhort@gmail.com \\ ${ }^{3}$ Email:wakobiratu@gmail.com \\ "Email: zehaylians@yahoo.com Tel:+251-920442207
}
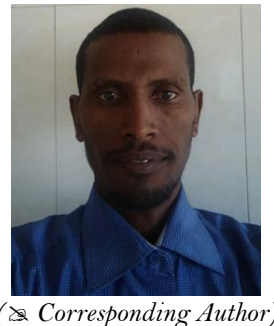

\begin{abstract}
Evaluation activity was conducted using four sweet potato varieties (Awassa-83, Kabode, Kulfo and Tulla) at Mehoni Agricultural Research Center (MeARC) during 2015 and 2016 testing years. The treatments were arranged in randomized complete block design with three replications. The analysis of variance table indicated the existence of significant variation among sweet potato varieties for all the characters considered in this study in both 2015 and 2016 testing years except number of nodes/plant and tuber diameter during 2016 cropping year. From this investigation, significantly higher marketable yield (29.20 t ha-1) and total yield (33.42 $\mathrm{t}$ ha- 1 ) were obtained from Kulfo variety. Overall, Kulfo was found well adapted and produced higher yield in the testing location. Hence, it is possible to use Kulfo variety for the production of marketable and total tuber yield by farmers and investors in Raya Azebo, Ethiopia.
\end{abstract}

Keywords: Sweet potato, Growth, Tuber diameter, Marketable yield, Total yield.

Citation | Haileslassie Gebremeskel; Kedir Jaleto; Wakuma Biratu; Haile Abebe (2018). Growth and Yield Response of Sweet Potato (Ipomoea batatas L. Lam) Varieties to Lowland Agro-Ecology of Raya Azebo, Ethiopia. Agriculture and Food Sciences Research, 5(2): 52-56.

History:

Received: 5 March 2018

Revised: 7 April 2018

Accepted: 9 April 2018

Published: 12 April 2018

Licensed: This work is licensed under a Creative Commons Attribution 3.0 License (cc) B E

Publisher: Asian Online Journal Publishing Group
Contribution/Acknowledgement: Our especial thank also go to Tewodros Abrha and Halefom Hailu for their help in field works. Our sincere thanks also go to all who made input for this study.

Funding: The authors would like to acknowledge Mehoni Agricultural Research Center (MeARC) and Roots, Vegetables and Fruits Research Project for providing all the facilities and financial support during the entire experimentation.

Competing Interests: The authors declare that they have no conflict of interests.

Transparency: The authors confirm that the manuscript is an honest, accurate, and transparent account of the study was reported; that no vital features of the study have been omitted; and that any discrepancies from the study as planned have been explained.

Ethical: This study follows all ethical practices during writing.

\section{Contents}

1. Introduction

References 


\section{Introduction}

Sweet potato (Ipomoea batatas L. Lam); $2 \mathrm{n}=6 \mathrm{x}=90$ ) is a herbaceous dicotyledonous plant with creeping, perennial vines and adventitious roots. It belongs to family Convovulaceae (morning glory flowers) and is hexaploid which is usually considered the only Ipomoea species of economic importance [1]; [2]; [3]. Sweet potato is originated from South America and it is cultivated in China, Uganda, Nigeria, Indonesia, Tanzania, Vietnam, India and United States [4].

Sweet potato is highly heterozygous cross pollinated crop in which many of the traits show continuous variation. It is known for its resistance to drought, vigorous early growth and low input requirements [5]; [6]. Globally sweet potato is the seventh most important food crop after wheat, rice, maize, potato, barley and cassava and second most important root and tuber crop in the world after potato [3] however, in Sub-Saharan Africa sweet potato is the third most important tuber crop after cassava and yam [7]. Throughout the world 107.6 million tons of sweet potatoes are produced [8] whereas the world average storage root yield of sweet potato has been estimated to be $14.8 \mathrm{t} \mathrm{ha}^{-1}[9]$.

Sweet potato has large, starchy, sweet-tasting and tuberous roots which adapts to tropical and warm temperate regions [10]. High dry matter content is the main characteristic preferred by consumers and processors of sweet potato [11]. Storage-roots (root tubers) of sweet potato contain $30 \%$ dry matter that $70 \%$ of it starch, $5 \%$ sugar and 5\% protein with vitamin A, C and B. Especially orange colored sweet potatoes contain vitamin A (Beta carotene) and vitamin $\mathrm{C}[12]$. It is a relatively drought tolerant crop providing the highest dry matter content for human consumption [11]. Sweet potato provides comparatively high calorie at $152 \mathrm{MJ} \mathrm{ha}^{-1} \mathrm{day}^{-1}$. Other crops such as cassava, wheat, rice and maize provide 121, 135, 151 and $159 \mathrm{MJ} \mathrm{ha}^{-1}$ day-1 calories, respectively [13]; [2].

In Ethiopia, among the most important root and tuber crops, sweet potato is one of the major traditional food crops [14]. It is cultivated in Ethiopia mostly for human consumption and as animal feed. It ranks third after Enset (Ensete ventricosum (Welw.) Cheesman,) and potato (Solanum tuberosum L.) as the most important root crop produced in the country [15]. The Ethiopian national average storage root yield of sweet potato is $8 \mathrm{t} \mathrm{ha}^{-1}$ while experimental storage roots yields ranging between 30 and $73 \mathrm{t} \mathrm{ha}^{-1}[16]$; [17]. According to those authors yields obtained in Ethiopia are generally low; however, there is good potential for the crop since climatic and soil factors are largely favourable.

It is an attractive crop among Ethiopian farmers due to its high productivity, universal uses, high caloric content and good taste, tolerant to adverse environmental conditions such as drought, low soil fertility, high rainfall and it requires very little labor and care compared to other crops [5]. According to these authors in Ethiopian, sweet potato is commonly grown by farmers in complex, mixed cropping systems where they normally plant several varieties with different characteristics like that of yield, maturity, root size, shape and disease and drought tolerance. Farmers may use the vines left in the fields to improve soil fertility and the crop is used in crop rotation.

Despite the various advantages of sweet potato have, research work on adaptability of the plant is very limited. In general, lack of information on performance evaluation and appropriate agronomic practices is considered to be among the major hindrance to embark on higher production and wisely utilization of this valuable plant in the country. Thus, it is necessary to evaluate the adaptability that would enable to maximize growth and yield in order to diversify and popularize this economically important plant in study area. Therefore, the objective of this study was to study the growth and yield response of sweet potato varieties to lowland agro-ecology of Raya Azebo.

\section{Material and Methods}

Five months old sweet potato mother plant introduced from Hawassa Agricultural Research Center (HARC) was used as a planting material for this experiment. The experiment was carried out at Mehoni Agricultural Research Center (MeARC), Ethiopia in 2015 and 2016 cropping season. The center is situated at about $678 \mathrm{~km}$ north of the Addis Ababa. Geographically it is located at $12^{\circ} 41^{\prime} 50^{\prime \prime}$ North latitude and $39^{\circ} 42^{\prime} 08^{\prime \prime}$ East longitude with an altitude of 1578 m.a.s.l. The site receives mean annual rainfall of $430-750 \mathrm{~mm}$ with an average minimum and maximum temperature of 18 and $25^{\circ} \mathrm{C}$, respectively. The soil textural class of the experimental area is clay loam (Vertisol) with $\mathrm{pH}$ of 7.9 .

The experiment consisted of four sweet potato varieties (Awassa-83, Kabode, Kulfo and Tulla) and it was arranged in randomized complete block design (RCBD) with three replications according to Gomez and Gomez [18]. Thus, there were four treatments in each replication. The space between rows and plants was $75 \times 30 \mathrm{~cm}$ having a plot size of $4.50 \times 3.60 \mathrm{~m}\left(16.20 \mathrm{~m}^{2}\right)$ and 72 plants per plot will be considered. The space between replications and plots will be $1.5 \mathrm{~m}$ and $1 \mathrm{~m}$, respectively. Plants in the four middle rows out of the six rows per plot were constitute the net plot to be used as the sampling units. Eight plants from the middle rows were taken for sampling and data analysis. All appropriate agronomic practices such as weeding, watering and hoeing were conducted manually at the experimental field.

Data on emergence percentage, plant height, number of nodes/plant, internodes length, tuber length, tuber diameter, marketable yield/ha, unmarketable yield/ha and total tuber yield/ha were recorded when yellowing and falling of leaves and also cracking of the soil was observed in the experimental plots. Statistical analysis of experimental data was subjected to analysis of variance (ANOVA) using SAS PROC GLM (2002) at $P<0.05$. Differences between means were evaluated using Least Significant Difference (LSD) Test at $P<0.05$.

\section{Result and Discussion}

\subsection{Variation in Growth and Yield Characters of Sweet Potato}

Mean square from analysis of variance table for all the traits tested for two respective years are summarized Table 1, 2 and 3. The performance of all tested varieties were found statistically different $(\mathrm{P}<0.05)$ in internode length and tuber length, highly significant $(\mathrm{P}<0.01)$ in number of nodes/plant and very highly significant $(\mathrm{P}<0.001)$ in emergence percentage, plant height, tuber diameter, marketable yield, unmarketable yield and total yield during 2015 cropping year. However in 2016, number of nodes/plant and tuber diameter did not significantly influenced $(\mathrm{P}>0.05)$ by varietal difference. Whereas emergence percentage and plant height were significantly 
affected $(\mathrm{P}<0.05)$ by sweet potato variety; which however, highly significant influence $(\mathrm{P}<0.01)$ was found in internodes length and tuber length and very highly significant $(\mathrm{P}<0.001)$ in marketable yield, unmarketable yield and total tuber yield of sweet potato varieties. This implies that the different genotypes were exerted significant influence on the growth and yield characters of sweet potato.

Table-1. Mean square of growth and yield response of sweet potato during 2015 and 2016 testing years

\begin{tabular}{|c|c|c|c|c|c|c|c|}
\hline \multirow{2}{*}{$\begin{array}{l}\text { Source of } \\
\text { variation }\end{array}$} & \multirow{2}{*}{$\begin{array}{c}\text { Degree of } \\
\text { freedom }\end{array}$} & \multicolumn{2}{|c|}{ Emergence percentage } & \multicolumn{2}{|c|}{ Plant height $(\mathrm{cm})$} & \multicolumn{2}{|c|}{ Number of nodes/plant } \\
\hline & & 2015 & 2016 & 2015 & 2016 & 2015 & 2016 \\
\hline Replication & 2 & 48.08 & 10.76 & 0.002 & 0.01 & 9.59 & 14.07 \\
\hline Variety & 3 & 820.81 **** & $141.24^{*}$ & $0.068^{* * * *}$ & $0.05^{*}$ & $95.48^{* * *}$ & $15.99^{\text {ns }}$ \\
\hline Error & 6 & 16.51 & 21.48 & 0.002 & 0.01 & 5.21 & 14.02 \\
\hline \multicolumn{2}{|c|}{$\mathrm{CV}(\%)$} & 5.44 & 4.99 & 4.19 & 6.18 & 5.52 & 8.97 \\
\hline
\end{tabular}

Note: * Significant at $\mathrm{P}<0.05 ;{ }^{*} *$ =Significant at $\mathrm{P}<0.01$ and ${ }^{*} * *=$ Significant at $\mathrm{P}<0.001$ probability level. $\mathrm{CV}=$ Coefficient of variation

Table-2. Mean square of growth and yield response of sweet potato during 2015 and 2016 testing years

\begin{tabular}{|c|c|c|c|c|c|c|c|}
\hline \multirow{2}{*}{$\begin{array}{l}\text { Source of } \\
\text { variation }\end{array}$} & \multirow{2}{*}{$\begin{array}{l}\text { Degree of } \\
\text { freedom }\end{array}$} & \multicolumn{2}{|c|}{ Internode length(cm) } & \multicolumn{2}{|c|}{ Tuber length(cm) } & \multicolumn{2}{|c|}{ Tuber diameter(cm) } \\
\hline & & 2015 & 2016 & 2015 & 2016 & 2015 & 2016 \\
\hline Replication & 2 & 0.03 & 0.18 & 0.49 & 1.91 & 0.12 & 0.13 \\
\hline Variety & 3 & $0.91 *$ & 33.71 ** & $8.16^{*}$ & $54.91 * *$ & $6.57 * * *$ & $1.02^{\mathrm{ns}}$ \\
\hline Error & 6 & 0.10 & 0.07 & 1.09 & 3.48 & 0.05 & 0.40 \\
\hline \multicolumn{2}{|c|}{$\mathrm{CV}(\%)$} & 5.94 & 7.95 & 6.33 & 8.77 & 4.18 & 10.22 \\
\hline
\end{tabular}

Table-3. Mean square of growth and yield response of sweet potato during 2015 and 2016 testing years

\begin{tabular}{|c|c|c|c|c|c|c|c|}
\hline \multirow{2}{*}{$\begin{array}{l}\text { Source of } \\
\text { variation }\end{array}$} & \multirow{2}{*}{$\begin{array}{l}\text { Degree of } \\
\text { freedom }\end{array}$} & \multicolumn{2}{|c|}{ Marketable yield $\left(\mathrm{t} \mathrm{ha}^{-1}\right)$} & \multicolumn{2}{|c|}{ Unmarketable yield $\left(\mathrm{t} \mathrm{ha}^{-1}\right)$} & \multicolumn{2}{|c|}{ Total yield $\left(\mathrm{t} \mathrm{ha}^{-1}\right)$} \\
\hline & & 2015 & 2016 & 2015 & 2016 & 2015 & 2016 \\
\hline Replication & 2 & 115.10 & 22.77 & 0.64 & 24.89 & 114.52 & 176.27 \\
\hline Variety & 3 & $37526.51 * * *$ & $31030.70^{* * * *}$ & 703.51 **** & $1141.79^{* * *}$ & $48299.54 * * *$ & $46648.58^{* * * *}$ \\
\hline Error & 6 & 91.92 & 359.30 & 13.27 & 19.57 & 109.55 & 206.72 \\
\hline \multicolumn{2}{|c|}{$\mathrm{CV}(\%)$} & 6.60 & 12.37 & 14.93 & 20.70 & 6.19 & 8.30 \\
\hline
\end{tabular}

Note: $n s=$ not significant at $\mathrm{P}<0.05$, $^{*}=$ significant at $\mathrm{P}<0.05$; ** =significant at $\mathrm{P}<0.01$ and *** =significant at $\mathrm{P}<0.001$ probability level. $\mathrm{CV}=$

Coefficient of variation

\subsection{Performance Variation in Growth and Yield of Sweet Potato}

The mean performances of sweet potato varieties are summarized in Table 4, 5 and 6. Comparing among the tested varieties the highest emergence percentage (98.61\%) was found at variety Kabode during 2016 testing year. While emergence percentage $(94.91 \%$ and $94.41 \%)$ recorded at Kulfo and Tulla varieties, respectively were statistically at par with Kabode during the same testing year. However, the lowest emergence percentage (50.31\%) was obtained at Tulla variety when the experiment was conducted in 2015 cropping year.

The highest overall mean emergence percentage $(90.46 \%)$ was recorded at Kabode whereas the lowest value $(72.61 \%)$ was recorded at Tulla variety. Significantly higher plant height $(1.74 \mathrm{~cm})$ and number of nodes/plant (48.67) were obtained from Awassa-83 variety during 2016 and 2015 cropping year, respectively; which however, significantly lower value $(1.02 \mathrm{~cm})$ and 35.02 plant height and number of nodes/plant were recorded at variety Awassa-83 and Kabode varieties during 2015 testing year.

Kabode produced significantly higher internode length $(5.65 \mathrm{~cm})$ and tuber length $(26.33 \mathrm{~cm}) \mathrm{during} 2015$ and 2016 cropping season; respectively. However, internode length obtained from Kabode variety in 2015 was not statistically different with the value obtained from Kulfo $(5.46 \mathrm{~cm})$ and Tulla $(5.39 \mathrm{~cm})$ varieties. On the other hand, the lowest internode length $(2.92 \mathrm{~cm})$ and tuber length $(14.03 \mathrm{~cm})$ were found at Kabode and Awassa-83 varieties when the experiment was carried out during 2016 and 2015, respectively. This result in harmony with the findings of Teshome, et al. [19]; Yahay, et al. [20] in sweet potato.

Tuber diameter was significantly influenced in the first year; which however, it did not significantly affected by varietal difference in the second testing year. Even though there was no significant effect on tuber diameter in the second cropping year Kulfo produced slightly higher tuber diameter $(6.96 \mathrm{~cm})$ while the lowest value $(3.48 \mathrm{~cm})$ obtained from Awasssa-83 in 2015 testing year. Similar result with this finding [21] was also reported on sweet potato response to fertilizer trial.

Concerning the yield parameters, all the three yield characters were influenced by varietal difference in both testing years. Kulfo produced significantly higher marketable yield $\left(29.20 \mathrm{t} \mathrm{ha}^{-1}\right)$ followed by same variety $(26.57 \mathrm{t}$ $\left.\mathrm{ha}^{-1}\right)$ in 2015 and 2016 cropping season, respectively. However, the lowest marketable yield $\left(2.16 \mathrm{t} \mathrm{ha}{ }^{-1}\right)$ and $(3.21 \mathrm{t}$ $\mathrm{ha}^{-1}$ ) were obtained from Awassa-83 variety while the experiment is implemented during 2015 and 2916 , respectively. Overall, mean marketable yield varied from 27.98 to $2.68 \mathrm{t} \mathrm{ha}^{-1}$ among the testing genotypes in both cropping seasons.

Unmarketable yield/ha was significantly influenced by genotypic difference in both testing years. The maximum unmarketable yield $\left(4.71 \mathrm{t} \mathrm{ha}^{-1}\right)$ was obtained at variety Kulfo along with the testing year of 2016 followed by $\left(4.22 \mathrm{t} \mathrm{ha}^{-1}\right)$ at the same variety when the research experiment conducted in 2015 testing year; whereas, the minimum value (0.30 $\left.\mathrm{t} \mathrm{ha}^{-1}\right)$ was obtained at Awassa-83 variety in 2016 cropping year. The highest sweet potato total tuber yield $\left(33.42 \mathrm{t} \mathrm{ha}^{-1}\right)$ was obtained from Kulfo variety in 2015 followed by $\left(31.48 \mathrm{t} \mathrm{ha} \mathrm{h}^{-1}\right)$ from the same variety during 2016; while the lowest total yield (2.58 $\mathrm{t} \mathrm{ha}^{-1}$ ) was obtained from Awassa-83 in 2016 testing year. From the mean comparison table Kulfo variety was produced significantly higher $\left(32.45 \mathrm{t} \mathrm{ha}^{-1}\right) \mathrm{mean}^{\mathrm{total}}$ tuber yield. These results are in agreement with findings of Kathabwalika, et al. [22] in sweet potato. 
Table-4. Mean performance of growth and yield of sweet potato varieties tested at Raya Azebo during 2015 and 2016 cropping season

\begin{tabular}{l|c|c|c|c|c|c|c|c|c}
\hline \multirow{2}{*}{ Variety } & \multicolumn{2}{|c|}{ Emergence percentage } & \multicolumn{3}{c|}{ Plant height (cm) } & \multicolumn{3}{c}{ Number of nodes/plant } \\
\cline { 2 - 11 } & $\mathbf{2 0 1 5}$ & $\mathbf{2 0 1 6}$ & Mean & $\mathbf{2 0 1 5}$ & $\mathbf{2 0 1 6}$ & Mean & $\mathbf{2 0 1 5}$ & $\mathbf{2 0 1 6}$ & Mean \\
\hline Awassa-83 & $86.76 \mathrm{a}$ & $82.87 \mathrm{~b}$ & 84.82 & $1.02 \mathrm{c}$ & $1.74 \mathrm{a}$ & 1.38 & $48.67 \mathrm{a}$ & 42.08 & 45.38 \\
\hline Kabode & $82.31 \mathrm{a}$ & $98.61 \mathrm{a}$ & 90.46 & $1.06 \mathrm{bc}$ & $1.59 \mathrm{ab}$ & 1.33 & $35.02 \mathrm{c}$ & 42.67 & 38.85 \\
\hline Kulfo & $79.43 \mathrm{a}$ & $94.91 \mathrm{a}$ & 87.17 & $1.15 \mathrm{~b}$ & $1.41 \mathrm{~b}$ & 1.28 & $40.00 \mathrm{~b}$ & 38.42 & 39.21 \\
\hline Tulla & $50.31 \mathrm{~b}$ & $94.91 \mathrm{a}$ & 72.62 & $1.36 \mathrm{a}$ & $1.57 \mathrm{ab}$ & 1.47 & $41.67 \mathrm{~b}$ & 43.73 & 42.70 \\
\hline LSD (5\%) & 8.12 & 9.26 & & 0.10 & 0.19 & & 4.56 & $\mathrm{~ns}$ & \\
\hline CV (\%) & 5.44 & 4.99 & & 4.19 & 6.18 & & 5.52 & 8.97 & \\
\hline
\end{tabular}

Note: Means followed by the same letter with in the same column are not significantly different at $5 \%$ level of probability.

$\mathrm{CV}=$ Coefficient of variation, $\mathrm{LSD}=$ List significant difference

Table-5. Mean performance of growth and yield of sweet potato varieties tested at Raya Azebo during 2015 and $2016 \mathrm{cropping}$ season

\begin{tabular}{|c|c|c|c|c|c|c|c|c|c|}
\hline & \multicolumn{3}{|c|}{ Internode length (cm) } & \multicolumn{3}{|c|}{ Tuber length(cm) } & \multicolumn{3}{|c|}{ Tuber diameter $(\mathrm{cm})$} \\
\hline & 2015 & 2016 & Mean & 2015 & 2016 & Mean & 2015 & 2016 & Mean \\
\hline Awassa-83 & $4.42 \mathrm{~b}$ & $4.06 \mathrm{a}$ & 4.24 & $14.03 \mathrm{~b}$ & $23.27 \mathrm{a}$ & 18.65 & $3.48 \mathrm{c}$ & 5.56 & 4.52 \\
\hline Kabode & $5.65 \mathrm{a}$ & $2.92 \mathrm{~b}$ & 4.29 & $17.59 \mathrm{a}$ & $26.33 \mathrm{a}$ & 21.96 & $4.23 \mathrm{~b}$ & 5.83 & 5.03 \\
\hline Kulfo & $5.46 \mathrm{a}$ & $3.36 \mathrm{~b}$ & 4.41 & $17.02 \mathrm{a}$ & $17.64 \mathrm{~b}$ & 17.33 & $6.35 \mathrm{a}$ & 6.96 & 6.66 \\
\hline Tulla & $5.39 \mathrm{a}$ & $3.01 \mathrm{~b}$ & 4.20 & $17.13 \mathrm{a}$ & $17.79 \mathrm{~b}$ & 17.46 & $6.39 a$ & 6.31 & 6.35 \\
\hline $\operatorname{LSD}(5 \%)$ & 0.62 & 0.53 & & 2.09 & 3.73 & & 0.43 & ns & \\
\hline $\mathrm{CV}(\%)$ & 5.94 & 7.95 & & 6.33 & 8.77 & & 4.18 & 10.22 & \\
\hline
\end{tabular}

Note: Means followed by the same letter with in the same column are not significantly different at $5 \%$ level of probability.

$\mathrm{CV}=$ Coefficient of variation, $\mathrm{LSD}=$ List significant difference

\begin{tabular}{|c|c|c|c|c|c|c|c|c|c|}
\hline \multirow[t]{2}{*}{ Variety } & \multicolumn{3}{|c|}{ Marketable yield $\left(\mathrm{t} \mathrm{ha}^{-1}\right)$} & \multicolumn{3}{|c|}{ Unmarketable yield $\left(\mathrm{t} \mathrm{ha}^{-1}\right)$} & \multicolumn{3}{|c|}{ Total yield $\left(\mathrm{t} \mathrm{ha}^{-1}\right)$} \\
\hline & 2015 & 2016 & Mean & 2015 & 2016 & Mean & 2015 & 2016 & Mean \\
\hline Awassa-83 & $2.16 \mathrm{~d}$ & $3.21 \mathrm{~d}$ & 26.83 & $0.56 \mathrm{~d}$ & $0.30 \mathrm{c}$ & 4.26 & $2.71 \mathrm{~d}$ & $2.58 \mathrm{~d}$ & 26.45 \\
\hline Kabode & $11.90 \mathrm{c}$ & $11.63 \mathrm{c}$ & 117.64 & $2.09 \mathrm{c}$ & $1.05 \mathrm{c}$ & 15.70 & $13.99 \mathrm{c}$ & $12.68 \mathrm{c}$ & 133.34 \\
\hline Kulfo & $29.20 \mathrm{a}$ & $26.75 \mathrm{a}$ & 279.75 & $4.22 \mathrm{a}$ & $4.71 \mathrm{a}$ & 44.63 & $33.42 \mathrm{a}$ & $31.48 \mathrm{a}$ & 324.48 \\
\hline Tulla & $14.66 \mathrm{~b}$ & $19.73 \mathrm{~b}$ & 171.93 & $2.90 \mathrm{~b}$ & $2.47 \mathrm{~b}$ & 26.86 & $17.59 \mathrm{~b}$ & $22.53 \mathrm{~b}$ & 200.59 \\
\hline $\operatorname{LSD}(5 \%)$ & 19.09 & 37.87 & & 7.28 & 8.84 & & 20.91 & 28.73 & \\
\hline $\mathrm{CV}(\%)$ & 6.60 & 12.37 & & 14.93 & 20.70 & & 6.19 & 8.30 & \\
\hline
\end{tabular}

Note: Means followed by the same letter with in the same column are not significantly different at $5 \%$ level of probability.

$\mathrm{CV}=$ Coefficient of variation, LSD=List significant difference

\section{Conclusion}

The analysis of variance table indicated that all agronomic and yield characters had significantly affected by sweet potato genotypic difference in the 2015 cropping season; whereas, variety did not exert any significant influence on number of nodes/plant and tuber diameter traits. From this experimental study, significantly higher mean marketable yield $\left(27.98 \mathrm{t} \mathrm{ha}^{-1}\right)$, unmarketable yield $\left(4.46 \mathrm{tha}^{-1}\right)$ and total yield $\left(32.45 \mathrm{t} \mathrm{ha}^{-1}\right)$ were obtained from Kulfo variety. Generally, Kulfo was found well performed and produced higher yield in the testing location. Likewise, the values obtained in this experiment demonstrated comparable and even higher values in yield characters with the different reports. Hence, it is possible to use Kulfo cultivar for the production of marketable and total tuber yield in Raya Azebo, Ethiopia.

\section{References}

[1] L. Degrass, The yam a tropical root crop. The technical centre for agricultural and rural cooperation (CTA). London: The Macmillian Press, 2000

[2] A. I. Abukari, M. W. Shankle, and K. R. Reddy, "Sweetpotato [Ipomoea batatas (L.) Lam.] Response to S-metolachlor and rainfall under three temperature regimes," American Journal of Plant Sciences, vol. 6, pp. 702-717, 2015. View at Google Scholar $\mid$ View at Publisher

C. Tortoe, "Microbial deterioration of white variety sweet potato (Ipomoea batatas) under different storage structures," International Journal of plant Biology, vol. 1, pp. 10-15, 2010.

[4] P. Milind and S. Monika, "Sweet potato as a super food," International Journal of Research in Ayurveda and Pharmacy, vol. 6, pp. 557$562,2015$.

[5] T. Assefa, A. Teshome, T. Engida, and T. Tesfaye, "Summary of progress on orange-fleshed sweet potato research and development in Ethiopia," in Proceedings of the 13th ISTRC Symposium, 2007, pp. 728-731.

[6] T. Engida, E. V. Devakara, and D. Nigussie, "Correlation and path analysis in sweet potato and their implications for clonal selection," Journal of Agronomy, vol. 5, pp. 391-395, 2007.

[7] P. T. Ewell and J. Mutuura, "Sweet potato in the food system of Eastern and Southern Africa. In: F. Ofori and S.K. Hahn (Eds.)," presented at the Symposium on Tropical Root Crops in a developing economy. Acta Hort, 1994.

[8] FAO, World information and early warning system on plant genetic resources. Rome: Food and Agriculture Organization of the United Nations, 2009.

[9] FAO, Production year book. Rome: Food and Agricultural Organization, 2000.

[10] M. Daniel and L. Gobeze, "Sweet potato agronomy research in Ethiopia; summary of past findings and future research directions," Agriculture and Food Sciences Research, vol. 3, pp. 1-11, 2016. View at Google Scholar | View at Publisher

[11] R. Placide, S. Hussein, L. Mark, and G. Daphrose, "Storage root formation, dry matter synthesis, accumulation and genetics in sweet potato," Australian Journal of Crop Science, vol. 7, pp. 2054-206 1, 2013. View at Google Scholar J. A. Woolfe, Sweet potato: An untapped food resource. Cambridge, UK: Cambridge University Press, 1992.

[13] D. E. Horton and H. Fano. Potato atlas; Atlas of the pomme de terre. Lima: Atlas of the Potato International Potato Center, 1985.

[14] T. Endale, B. Terefe, D. Mukgeta, and L. Geleta, "Improvement studies on enset and sweet potato," in Proceedings of the Second National Horticultural Workshop in Ethiopia, 1-3 Dec.1992. Addis Ababa, Ethiopia, 1994, 1994.

[15] CSA (Central Statistical Authority), Ethiopian agricultural sample enumeration vol. 146. Federal Democratic Republic of Ethiopia, Central Statistical Agency, Addis Ababa, Ethiopia, Statistical Bulletin, 2011.

[16] A. S. Bhagsari and D. A. Ashley, "Relationship of photosynthesis and harvest index of sweet potato yield," Journal of Horticultural Science, vol. 111, pp. 288-293, 1990. View at Google Scholar

[17] V. S. Varma, K. P. Singh, S. K. Singh, J. R. P. Singh, S. P. Verma, S. Mishra, M. P. Sahu, K. Kumari, and R. Ray, "Two high yielding selections of sweet potato," Journal of Root Crops, vol. 20, pp. 15-19, 1994. 
[18] K. A. Gomez and A. A. Gomez, Statistical procedures for agricultural research, 2nd ed. New York: John Wiley and Sons, 1984.

[19] A. Teshome, C. Amenti, and T. Kassaye, "Yield and yield components of sweet potato as influenced by plant density. In Adami Tulu Jido Kombolcha District, Central Rift Valley of Ethiopia," American Journal of Experimental Agriculture, vol. 1, pp. 40-48, 2011. View at Google Scholar | View at Publisher

[20] S. U. Yahay, A. M. Saad, S. G. Mohammed, and S. O. Afuape, "Evaluating the performance of improved sweet potato (Ipomoea Batatas L. Lam) advanced lines in Kano, Sudan Savanna of Nigeria," International Journal of Agronomy and Agricultural Research, vol. 7, pp. 52-60, 2015. View at Google Scholar

[21] F. Uwah, U. L. Undie, N. M. John, and G. O. Ukoha, "Growth and yield response of improved sweet potato (Ipomoea Batatas (L.) Lam) varieties to different rates of potassium fertilizer in Calabar, Nigeria," Journal of Agricultural Science, vol. 5, pp. 61-69, 2013. View at Google Scholar |View at Publisher

[22] D. M. Kathabwalika, E. H. C. Chilembwe, V. M. Mwale, D. Kambewa, and J. P. Njoloma, "Plant growth and yield stability of orange fleshed sweet potato (Ipomoea Batatas) genotypes in three agro-ecological zones of Malawi," International Research Journal of Agricultural Science and Soil Science, vol. 3, pp. 383-392, 2013. View at Google Scholar 